\title{
NOTES.
}

REPRODUCTION AND FERTILIZATION IN CYSTOPUS CANDIDUS.-In a paper read before Section D at the Edinburgh meeting of the British Association in 1892 , on the structure of this Fungus, I gave a short account of the cytology and development of the asexual and sexual reproductive organs. This paper was incomplete and in part somewhat incorrect; but since that time I have obtained fresh material and am now able to give a much fuller account, which will be published shortly in the Annals, and of which the following is a summary. The literature on this subject is not very extensive. Among those who have paid special attention to it are Fisch, Zalewski, Dangeard, and Chmielewsky. The results obtained by these observers are fully discussed in the complete paper.

The Fungus is found as a parasite on the leaves, stem, and ovaries of various cruciferous plants, especially the common Shepherd's Purse (Capsella Bursa-Pastoris), on which it forms white shining patches, often of considerable size. The mycelium consists of non-septate hyphae, which ramify in all directions between the cells of the hostplant, produce small spherical hustoria, which penetrate the cells, and under certain conditions cause hypertrophy of the organs attacked. The mycelium is at first found only in the superficial layers of the plant, but at a later stage it penetrates into the deeper layers, and even into the pith. In the earlier stages of development this mycelium produces club-shaped branches just beneath the epidermis, from which the asexual organs (spores or sporangia) are delimited; and at a later stage sexual organs (antheridia and oogonia) are produced on the ramifying mycelium, sometimes intercalary, sometimes terminal. The protoplasm of the hyphae is vacuolate, and consists of a loose network in which are to be found numerous small nuclei. In certain parts of 
the hyphae, especially where rapid growth is taking place, the protoplasm is much denser, and almost completely fills the cavity of the filament. The nuclei possess the same structure as those of the higher plants, and do not differ in any fundamental respect from those described by me as occurring in the mycelium of the Hymenomycetes. Each nucleus consists of a nuclear membrane, a network of linin which contains very little, if any, chromatin, and a nucleolus.

In the formation of asexual reproductive organs, protoplasm and nuclei pass into the club-shaped sporangiophores. A part of this protoplasm accumulates at the apex together with four or five nuclei. This is then separated by constriction of the cell-membrane and the formation of a double cell-wall, the sporangium being thus from the beginning a multi-nucleated cell. No fusion of the nuclei is to be observed in these basidia, as has been described in the basidia of the Hymenomycetes both by Rosen and myself.

The formation of oogonia takes place by terminal or intercalary swelling of the hyphae, into which large quantities of protoplasm pass together with nuclei. The nuclei appear to be plastic, inasmuch as they become irregular in shape during the rapid rush of the protoplasm, and appear at first in the young oogonium as knots in the protoplasm. According to Fisch the oogonium contains from ten to twenty nuclei, but I find a much larger number than this $-75,88,97$, and I I 5 having been counted in different oogonia. After an oogonium has been cut off it becomes turgid, the nuclei regain their shape, and they are then seen to be similar in size and appearance to those in the mycelium. They do not long retain this appearance however, but begin to increase in size; the linin-network stains more deeply, and the nucleolus becomes more indistinct. The same changes take place in the antheridium, in which about six to twelve nuclei are to be found.

The protoplasm of the oogonium now tends to contract away from the wall except at the place where it is in contact with the antheridium, at which point a fertilizing spot appears. The nuclei begin to move towards the periphery of the contracted protoplasm, and at the same time begin to divide. The division is karyokinetic, an equatorial plate and distinct spindle being formed. A deeply stained, finely granular mass of protoplasm (mistaken by Dangeard for an oilglobule) appears in the central clear part, and close to this is to be seen a single nucleus derived from the division of one of the oogonial nuclei. This is the nucleus of the ovum: the other nuclei become 
restricted to the periplasm. A fertilizing tube is now put out from the antheridium, into which passes a single nucleus derived from the division into two of one of the original antheridial nuclei, together with a small quantity of very deeply stained, finely granular protoplasm. The fertilizing tube penetrates deeply into the oosphere until it comes quite close to the female nucleus. The male nucleus is then expelled, and the fertilizing tube is gradually withdrawn from the oosphere, on which it then comes to lie obliquely. A delicate cellmembrane is produced around the oosphere, separating it from the periplasm. The male and female nuclei then fuse together in the centre of the deeply-stained protoplasm to produce the nucleus of the oospore. This nucleus then undergoes division into two, four, eight, sixteen, and thirty-two, and at the same time the thick endospore is produced on the inside of the primary membrane of the oosphere from the protoplasm of the oospore, the exosporial layers being formed at the same time from the periplasm and the degenerating periplasmic nuclei.

Chapel Allerton, Leeds.

HAROLD WAGER.

\section{PRELIMINARY NOTE ON THE RELATION BETWEEN CALCIUM AND THE CONDUCTION OF CARBOHYDRATES} IN PLANTS.-In I 875 Boehm (1) came to the conclusion that one of the functions of calcium is to aid in the conduction of carbohydrates in plants.

In his two papers A. F. W. Schimper (2) (3) added considerably to our knowledge of the rôle of calcium. In his first paper he subscribed to Boehm's views to a certain extent. In his second paper he demonstrated that in plants which normally contain crystals of calcic oxalate, oxalic acid is a bye-product of the synthesis of proteids, and that in the absence of calcium there is an abnormal accumulation of acid potassic oxalate in leaves and buds. He showed farther that this soluble oxalate acts as a poison. He therefore concluded that the use of calcium is to neutralize this poisonous salt. Schimper also proved that sugar can travel in leaves containing no appreciable amount of calcium; that carbohydrates sometimes travel from the seeds up the stem of the seedling without any corresponding emigration of calcium. Finally, he pointed out that in plants cultivated without calcium, though the terminal bud might be dying, yet at the 


\section{$2 \mathrm{BHL}$ Biodiversity Heritage Library}

Wager, Harold W. T. 1896. "Reproduction and fertilization in Cystopus candidus." Annals of botany 10, 89-91. https://doi.org/10.1093/oxfordjournals.aob.a088601.

View This Item Online: https://www.biodiversitylibrary.org/item/235772

DOI: https://doi.org/10.1093/oxfordjournals.aob.a088601

Permalink: https://www.biodiversitylibrary.org/partpdf/318410

\section{Holding Institution}

Smithsonian Libraries

\section{Sponsored by}

Biodiversity Heritage Library

\section{Copyright \& Reuse}

Copyright Status: Not in copyright. The BHL knows of no copyright restrictions on this item.

This document was created from content at the Biodiversity Heritage Library, the world's largest open access digital library for biodiversity literature and archives. Visit BHL at https://www.biodiversitylibrary.org. 